\title{
Flooding in Informal Settlements: Potentials and Limits for Household Adaptation in Dar es Salaam City, Tanzania
}

\author{
Regina John (1) \\ School of Spatial Planning and Social Sciences, Ardhi University, Dar es Salaam, Tanzania \\ Email: reginajohn2000@gmail.com
}

How to cite this paper: John, R. (2020). Flooding in Informal Settlements: Potentials and Limits for Household Adaptation in Dar es Salaam City, Tanzania. American Journal of Climate Change, 9, 68-86. https://doi.org/10.4236/ajcc.2020.92006

Received: December 14, 2019

Accepted: May 4, 2020

Published: May 7, 2020

Copyright $\odot 2020$ by author(s) and Scientific Research Publishing Inc. This work is licensed under the Creative Commons Attribution International License (CC BY 4.0).

http://creativecommons.org/licenses/by/4.0/

\section{(c) (i) Open Access}

\begin{abstract}
Rapid urbanization and climate change are compounding the vulnerability of the urban poor to natural hazards, particularly in the global south. Large number of the population in cities of developing countries live in informal settlements characterized with lack of infrastructure facilities and services. Majority of the informal settlements are located in risk areas such as low-lying lands and river banks whereby climatic threats associated with flooding are common. The urban informal settlements are thus disproportionately more vulnerable due to their greater exposure associated with their geophysical location, under-invested infrastructure facilities as well as poor housing quality. While it is widely acknowledged that the need to adapt to climate change related hazards such as flooding is no longer an option, literature suggests that potentials and opportunities for adaptation are unevenly distributed among global regions, communities, sectors, ecological systems as well as across different time periods. This study sought to explore the potentials and limits of households living in flood prone in an informal settlement of Magomeni Suna, Dar es Salaam Tanzania. The study employed a mixed method research design using both quantitative and qualitative data collection and analysis. Quantitative data were collected through a structured questionnaire administered to 199 randomly selected respondents, while non participant observation was used to capture information related to household physical adaptation measures. Key informant interviews were used to elicit data from purposively selected representatives of government and other local institutions. Two focus group discussions supplemented the data collected through the other methods. The results show that households employ multiple options for flood adaptation ranging from structural measures aimed at preventing flood water from entering the houses, to action oriented strategies
\end{abstract}


such as relocation. The results also highlight there exist potentials like strong social networks, cohesive communities, and presence of various local institutions willing to support household responses to floods. Limitations to flood adaptation include little support and ad hoc intervention by government authorities, as well as meagre household income. To enhance household adaptation to flood hazards, policy measures towards enhancing social networks and community actions for flood adaptation are necessary. There is also a need to enhance multi institutional involvement as well as promote local livelihoods so as to improve household adaptation to floods.

\section{Keywords}

Flooding, Informal Settlements, Adaptation, Dar es Salaam City

\section{Introduction}

More than half of the global population (55 percent) now live in urban areas. The figure is projected to increase to 68 percent by 2050 at a growing rate of 65 million urban dwellers annually (UN-HABITAT, 2016). Projections show that urbanization, the gradual shift in residence of the human population from rural to urban areas, combined with the overall growth of the world's population could add another 2.5 billion people to urban areas by 2050, with close to 90 percent of this increase taking place in Asia and Africa (UN-DESA, 2019). Sub-Saharan Africa (SSA) is often regarded as the world's fastest urbanizing region. The urban areas currently contain 472 million people and will double over the next 25 years. According to the World Population Prospects, the 2018 revision, produced by the Population Division of the UN Department of Economic and Social Affairs (UN-DESA) the global share of African urban residents is projected to grow from 11.3 percent in 2010 to 20.2 percent by 2050 (UN-DESA, 2019).

The fattest urbanization rates of most of the developing countries including those in Africa are coupled with improper urban development. The growth in urban population is often characterized by informality, illegality and unplanned settlements, and above all, is strongly associated with urban poverty. When rapid urbanization is poorly managed and occurs in the context of existing widespread poverty, developing countries increase their risk and deplete their resilience or ability to respond to different hazards and disaster events. The urban centers in most of the developing countries are frequently impacted by natural disasters and threats that arise from, or are exacerbated by, the impacts of climate change. Cities are increasingly exposed to both water scarcity and intense flooding due to extreme changes in weather patterns across the globe.

It is estimated that one third of the world's population is living in informal settlements and the largest proportion of these is in low income countries of Africa and Asian regions (UN-HABITAT, 2010). These informal settlements or 
"slums" are often reliant on nonexistent or incompetent risk-reduction services. The United Nations Human Settlements Programme (UN-HABITAT) defines slum as a contiguous settlement that lacks one or more of the following five conditions: access to clean water, access to improved sanitation, sufficient living area that is not overcrowded, durable housing and secured tenure. Slums are believed to be the products of failed policies, poor governance, corruption, inappropriate regulation, dysfunctional land markets, unresponsive financial systems, and lack of political will. Cities of developing countries including those in Africa are threatened to increased inequality, growth of slums and disastrous impacts of climate change as a result of unplanned and un-managed urbanization. Most of the urban centers lack access to adequate infrastructure and basic services such as safe drinking water, proper sanitation and drainage, and health care access. Indeed, urban centers across the developing world with "development deficit" are at increased risk of disaster impact.

Recent estimates show that the proportion of the urban population living in slums as compared to the rest of the urban population in the developing world decreased from 46.2 per cent in 1990 to 29.7 percent in 2014 (UN-HABITAT, 2016). However, the estimates further show that the absolute number of slum dwellers in the developing world is on the increase given that over 880 million residents lived in slums in 2014 as compared to 689 million in 1990, representing an increase of 28 percent in the absolute numbers of slum dwellers over the past 24 years. The increase in number of people living in slums/informal settlements in developing world demonstrates the failure of cities to keep pace with urban growth. Sub Saharan Africa exhibit a steep rise of 72 million new slum dwellers and accounts for 56 per cent of the total increase in the number of slum dwellers among developing regions between 1990 and 2014. Indeed, the number of slum dwellers in Sub-Saharan Africa has grown in tandem with growth in the region's urban population and it demonstrates the failure of cities to keep pace with urban growth.

According to the UN HABITAT, urban areas around the world are facing greater challenges related to growing number of residents residing in informal settlements and in providing urban services than they did over the past two decades. The informal settlements are often located in areas most exposed to the effects of global climate change, notably low-lying areas, steep slopes, and ravines. Here, it is the population that is at higher risk from cyclones, floods, earthquakes, infectious diseases and other urban risks, lives in poor conditions, whose basic needs are not always provided for. The emerging urban issues include climate change impacts; exclusion and rising inequality; rising insecurity; and upsurge in international migration.

Literature indicates that climate change induced flood hazard is one among the frequent hazard types causing highest impacts in most of the African cities (UN-HABITAT, 2007 \& 2010; Olorunfemi, 2011). Dar es Salaam, Tanzania's largest city, with over 4 million inhabitants, is one example which significantly 
suffers the negative impacts of flood hazards. It has been identified as one of the largest coastal cities in Africa highly vulnerable to flooding and sea level rise (UN-HABITAT, 2008). Heavy rainfall frequently causes flooding in the city, particularly in informal settlements, which tend to be located in high-risk flood areas. Dar es Salaam is characterized by urban sprawl and expanding informal settlements, resulting from increasing population pressure, poor infrastructure and inadequate urban planning. About 70 percent of the city population and 80 percent of the housing stock are in informal settlements including the low-lying areas.

While all people living in areas at risk from natural hazards can be vulnerable in terms of exposure (Handmer, 2003), it is widely acknowledged that the effects of climate change will disproportionately increase the vulnerability of the urban poor compared to other groups of urban dwellers (IPCC 2014; Skoufias et al., 2011; Georgeson et al., 2016). Literature shows that, given the frequency of floods in certain communities, those affected develop their own adaptation strategies to protect their families and assets (Agrawal, McSweeney, \& Perrin, 2008; Dodman et al., 2011). The abilities to capitalize on available opportunities that enable the carrying out of adaptation strategies while overcoming the limits that make adaptation processes difficult, determines the actor's adaptive capacity. Although the literature on the factors that contribute to adaptive capacity has deepened (Adger et al., 2009; Moser \& Ekstrom, 2010), the existing studies suggests significant work remains in understanding context-specific determinants of vulnerability and adaptive capacity (Tol \& Yohe, 2007; Hinkel, 2011; Biesbroek et al., 2013). It is argued that while some level of generalization regarding opportunities and constraints for adaptation that are common to different regions, sectors, communities, and actors is possible, the manner in which they manifest is context dependent (Adger et al., 2007; Weichselgartner \& Breviere, 2011; IPCC, 2012). The aim of this paper is to contribute to the understanding of the context specific potentials and limits of households in adapting to flooding using a specific case of an informal settlement in Dar es Salaam City, Tanzania.

\section{The Concept of Adaptation}

Adaptation to climate change is defined by the Intergovernmental Panel on Climate Change (IPCC) as "adjustment in natural or human systems in response to actual or expected climatic stimuli or their effects, which moderates, harm or exploits beneficial opportunities" (IPCC, 2007: WG II-869). The term "adaptation" travels along with other constructs such as "coping" and "recovery" and the literature shows that there are many forms and levels of adaptations that can be classified in many ways. Further differentiations mainly include the notions of timing relative to stimulus (anticipatory, concurrent, reactive), intent (autonomous, planned), spatial scope (local, regional national, widespread) and form or type of actions (technological, behavioral, financial, institutional, informational) (Smit et al., 2000; Smit \& Skinner, 2002). Parry et al. (2007) further dis- 
tinguishes adaptation in terms of the actor that takes adaptation measures (national or local government, international donors, private sector, NGOs, local communities and individuals), and their climatic zone (dry land, floodplains, mountains, Arctic).

Presence of adaptive capacity is a necessary condition for the design and implementation of effective adaptation strategies so as to reduce the likelihood and the magnitude of harmful outcomes resulting from climate change (Brooks et al. 2005). Adaptive capacity is considered to be influenced not only by economic development and technology, but also by social factors such as human capital and governance structures (Adger et al., 2007). Klein et al. (2014) re-affirms these views while stating that significant work remains in understanding context specific and interrelated determinants of household's adaptive capacity.

The forces that influence the ability of a system to adapt are the drivers or determinants of adaptive capacity (Adger et al., 2003; Blaikie et al., 1994). For example, a strong kinship network may play an important role in a subsistence-based society, and quite a different role in a developed world agribusiness context where financial and institutional structures will influence adaptability. In accordance with this, Adger et al. (2005), defines adaptation as a dynamic social process and the adaptive capacity of societies is partly determined by the ability to act collectively through the social capital assets. Although local adaptive capacity can reflect broader conditions (Smit \& Pilifosova, 2003), national indicators often fail to capture many of the processes and contextual factors that influence adaptive capacity at a local level, and thus provide little insight on adaptive capacity at the level where most adaptations will take place (Eriksen \& Kelly, 2007). Analysis of the potentials and limits of households in adaptation to flooding in the informal settlements will thus inform on the processes and contextual factors for adaptive capacity, necessary for influencing building resilience at a local level.

\section{Background, Data and Method (Study Area and Data Collection)}

\subsection{Study Area}

The study was conducted in Magomeni Suna settlement, located about five kilometers from the City centre in Magomeni Ward, Kinondoni Municipality. According to the 2012 National Population Census, the settlement had a population of 9450 inhabitants with an approximate 2500 households (URT, 2013). The total number of houses is 770 of which 350 are estimated to be exposed to frequent floods. The settlement has both planned and unplanned land uses with the latter accounting for large part of the settlement. The unplanned land use runs from North, West and Eastern part of the settlement and this is the area that experiences frequent floods. The planned part which is approximately one eighth of the total settlement is found on the Southern part of the settlement as shown in Figure 1. 


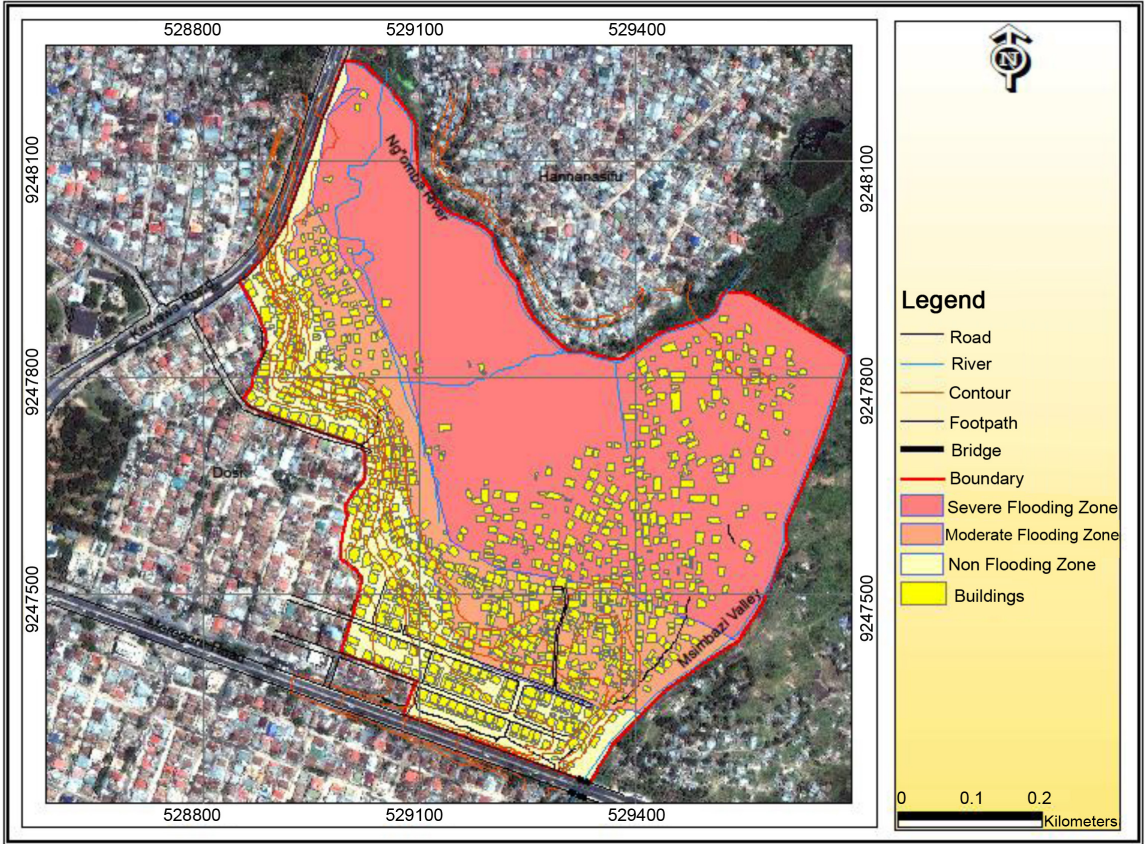

Figure 1. Map of the study area-Magomeni Suna settlement.

The settlement is bordered by two rivers, Msimbazi River to the West and $N g^{\prime}$ ombe River to the North. Until 1998 the residents experienced what they call "normal floods, ordinary floods" during rainy seasons, meaning these events were neither severe, nor destructive and residents could easily cope with them. In 1998, the settlement experienced the first destructive flood caused by El Niño, followed by flash floods in 2011 and subsequently in 2012 to 2015 .

\subsection{Study Design and Data Collection}

The study employed a mixed method research design and both quantitative and qualitative data were collected. Quantitative data were collected through a structured questionnaire administered to a sample of 199 respondents to gather information on household demographic and socio-economic status. The study sample was obtained by using a random sampling technique of households residing in Magomeni Suna. In the questionnaire survey, some open-ended questions were also included to explore the household experience of climate variability, flood hazards and adaptation strategies. Observation and mapping techniques were also employed to capture physical indicators of vulnerability related to availability and location of community facilities. Qualitative data were largely collected through key informant interviews and focus group discussions. A checklist of items for an in-depth interview was used to gather information from key informants consisting of Sub-ward leaders, Ward leaders and representative of local institutions. Likewise, a focus group interview guide was used in the discussion to gather information from two focus groups; one group of men and one of women, so as to obtain insights on vulnerability and adaptive capacity of households and communities in the respective socio and livelihood groups. 


\section{Results and Discussion}

\subsection{Household Demographic and Socio-Economic Characteristics}

Large proportion of households in the study area (90 out of 199 interviewed) had young dependents, one to two members below the age of 18 . The young dependent household members are considered to be more at risk when extreme events such as floods occur. The findings further show that household size ranges from one-person household to more than five household members with an average mean household size of 3.91. Households with five members plus represent the highest proportion, followed by households with four members, three members, two members and one person. The largest size of most of the households in the study area has an implication to their sensitivity to flood hazards. Cutter et al. (2003) noted that vulnerability is associated with family size arguing that larger households are more likely to have lower social status and therefore low adaptive capacity. However, the large household sizes may also be an important asset in reducing vulnerability through extended social networks and or enhanced household economy that may be realized through contribution of individual household members.

Education levels of most of the households in the study settlement are generally low. About 40 percent of the households investigated had members who attained only primary education and close to 48 percent, secondary education. Only 11 percent of household had members who attained tertiary education including University and technical college. One percent of the households had none of their members attained any level of education. Low education level is associated with lack of well-remunerated employment and therefore less power, fewer economic resources to anticipate, survive and recover from the effects of massive floods (Adger et al., 2004; Cutter et al., 2003).

Small businesses represent a major source of income to 80 percent of the households investigated (Figure 2). Most activities reported include food

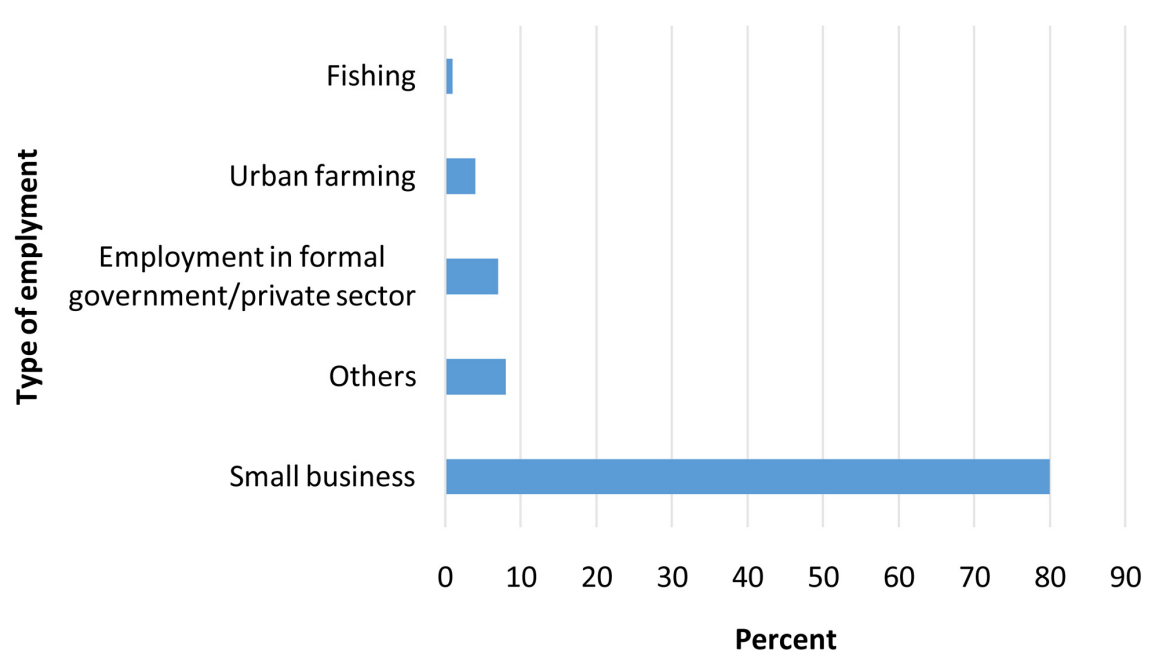

Figure 2. Major sources of income $(\mathrm{N}=199)$. 
vending, retail kiosks, selling vegetables and fruits. Majority of the business activities are operated within the household vicinity, therefore prone to damages in case of flooding. A mere 4 percent of household engages on urban farming largely vegetable growing along the Msimbazi River valley. Casual labouring in construction industries, tailoring, shoe repairing, as well as security guards in wealthier communities constitute other types of employment by the households.

The study findings further reveal a high degree of poverty and low incomes reflected in the employment types of the households. Data recorded during fieldwork show that around 24 percent of the households have monthly income less than TZS 100,000 ( $\$ 44)$ and 42 percent have monthly income between TZS $100,000$ to TZS 300,000 ( $\$ 44$ to $\$ 131)$. Only 20 percent have income between TZS 300,000 to 500,000 ( $\sim 131$ to $\$ 218)$ and 14 percent have income level above TZS 500,000 ( \$218).

\subsection{Household Experiences to Floods}

Ninety-three percent of the investigated households were found to be exposed to floods during different rainy seasons of a year. Being exposed means, that after a heavy rainfall excess water overflows the banks of the water course and spills out into adjacent buildings. The same occurs after light showers due to waste saturation in nearby rivers as well as the lack of sufficient storm water drainage systems. Local authorities (Sub-ward, Ward and Municipal Governments) are often blamed for the lack of maintenance of river channels. In almost 43 percent of the exposure cases, the water emerges knee high (approximately $1 \mathrm{feet}$ ) while in 9 percent of the cases, the water goes waist high (approximately 1.5 feet). In 17 percent and 31 percent cases, the water goes chest high (approximately 2 feet) and even above chest high (approximately $3 \mathrm{feet}$ ) respectively (Figure 3 ).

Households experience different kinds of damage due to flooding. The most reported negative effect experienced is the loss and/or damage of all or some of household assets including clothes, food storages and other material assets; destruction of business and loss of capital as well as loss of savings (Figure 4).

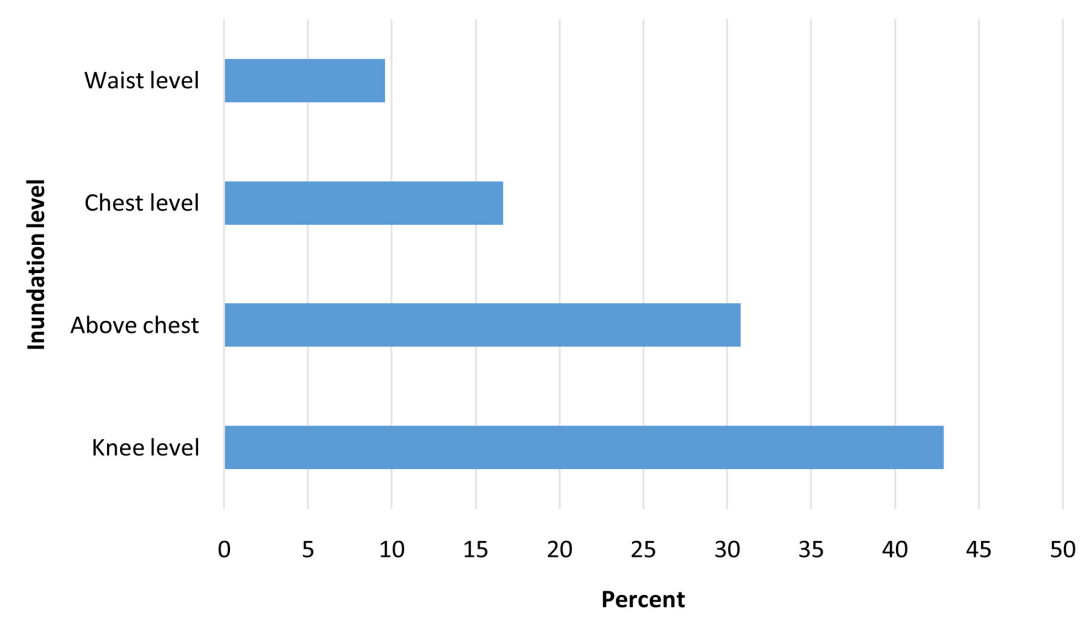

Figure 3. Flood inundation levels $(\mathrm{N}=199)$. 


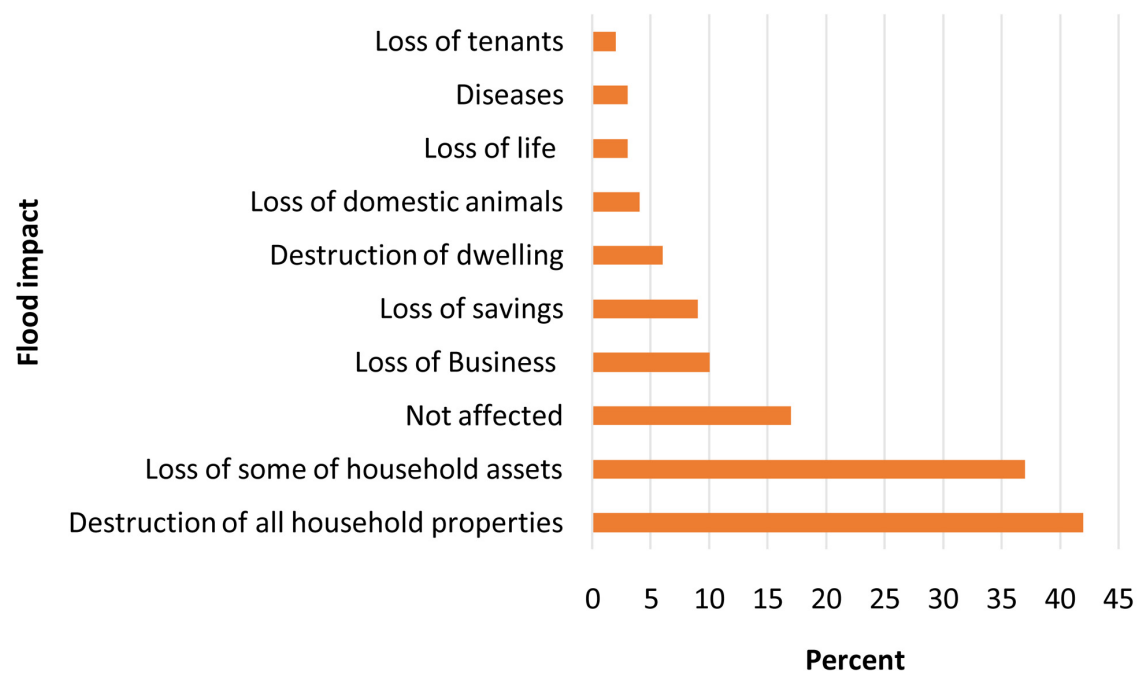

Figure 4. Household experience on flood damages (Multiple answers possible, $\mathrm{N}=263$ ).

While some of the household belongings are washed away as the water takes the meandering river course of the Indian Ocean, some are totally destructed after being immersed in water. Small businesses, which account for the major source of income to majority of the households, are also destructed by floods resulting in the loss of income of the households. Businesses are also affected even after flooding due to lack of customers as some of the people shift after floods. Those who earn their income from renting out rooms also suffered from reduced income because some of the tenants shift to other non-flooded areas.

\subsection{Household Adaptation Strategies}

Approximately 58 percent of households in the study area take precautionary measures before floods while 42 percent do not. Most of the anticipatory measures are physical and long-term measures meant to prevent flood water from entering the houses. These include construction of embankment or protection walls, raising door-steps and pit latrines, rubble filling around dwellings as well as fixing/repairing doors, windows and crack-on walls to make them strong. Foundation for buildings and door-steps are raised up to 1-meter-high above the ground (Figure 5) while protective walls of up to 0.5 meters' high are constructed in front of the buildings to reduce risk of flooding (Figure 6).

Although the structural measures are necessary in temporarily containing flood water outside the buildings especially during normal floods, they were proved to be insufficient in case of flashfloods such as those of 2011 and 2012. Along with the long-term anticipatory strategies, households take short term strategies to minimize flood damage by arranging high storage facilities within the dwellings. To do this, households create temporary higher structures using either bricks or wooden material to temporarily store items such as clothes, food storage and furniture during flooding events.

During the flooding events, households temporarily relocate from their original settlements to neighbors, friends and relatives until the water levels recede. 


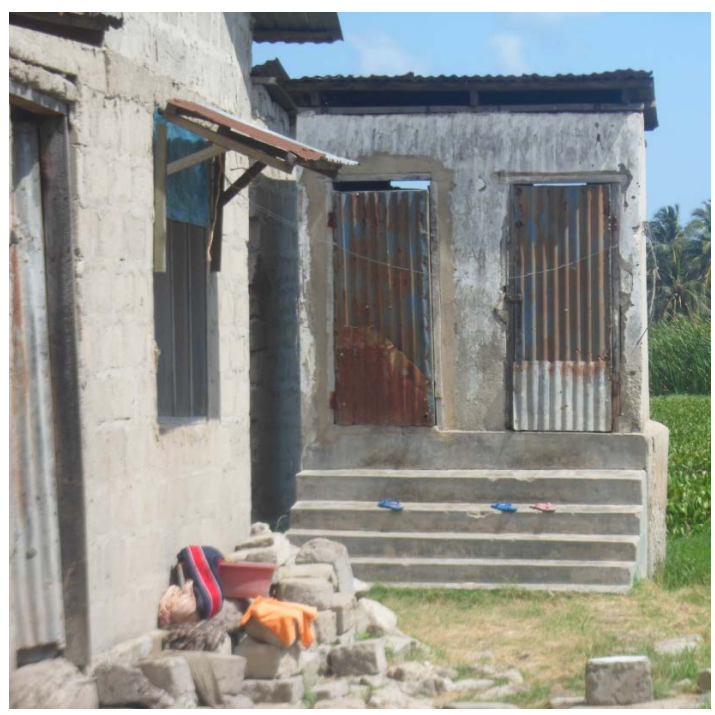

Figure 5. Pit latrine with raised foundation. Source: Author.

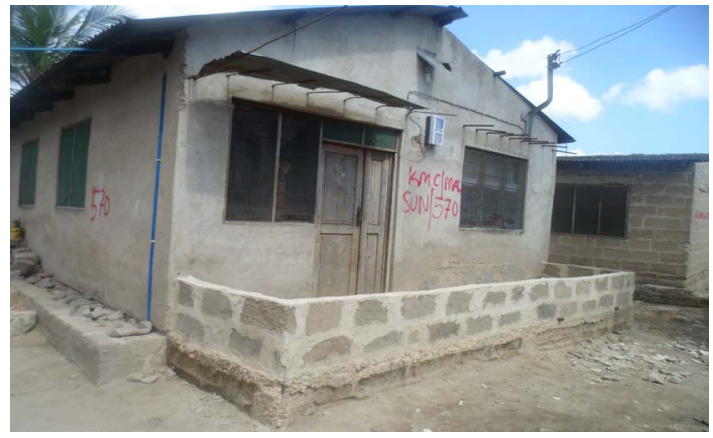

Figure 6. Protection wall securing main entrance. Source: Author.

Relocation commences by moving children, elders and sick persons and only when the flood persists other household members including women relocate to safer places. Men, the household heads, are the last ones to relocate as they remain behind to take care of the household belongings as directly quoted from one of the respondents:

“... When rain commences, we relocate women and children to safer areas and we men remain behind to take care of the house and other properties. We cannot leave the houses alone for security purposes, one of the household members lamented".

Relocation seems to be a phenomenon that happens at least once a year to most of the households as indicated by 95 percent of the households interviewed. The remaining 5 percent relocates at a range of two to five times a year. This suggests the severity of the impact of flood in the area. Overall, the duration of relocation varies from less than one week to a month. It is worth pointing out that relocation is temporary as households normally get back after floods, although for tenants, some decide to search for accommodation in other places. 
Permanent relocation is not a preferred option, due to strong socio-economic ties the residents have with the settlement. The households therefore accept the flood risk fatalistically and rely on the faith to get them through the crisis, in accordance to the Wamsler's idea on the power of faith while others believe as "emotionally oriented strategies of adaptation" (Wamsler, 2007: p. 119).

Households also take action-oriented strategies which involve transporting material assets to non-flooding areas to relatives and neighbors (Figure 7(a) and Figure 7(b)). Others also store their belongings in water-proof containers such as polythene bags or water buckets which are then kept on ceiling boards or on furniture above flood level.

Flooding results into blockage of access ways due to inundation of flood water, consequently leading to limited mobility. In response to this, households place sandbags and tree logs as footbridges and access ways. The use of sandbags is also meant to prevent erosion, along river-banks or of the dwellings. Again, this strategy is only suitable during the low depth floods while remains ineffective during high depth floods.

While the anticipatory measures identified in the study are related to hasty security procedures and relocation, responsive strategies are associated with prevention and the re-organization of life and activities with focus on returning to "normal". These measures include, cleaning up to remove mud deposits, washing up different house items as well as repairing damaged furniture and/or dwelling structures (Figure 8). While cleaning activities deploy largely human resources composed mostly of family members, building repair requires financial resources and by and large is undertaken at a slower pace when funds are available. Other flood responsive measures include construction of protection on building fronts, embankment on river sides, and rubble filling (Figure 8).

Residents make financial contributions as well as volunteer their time to clean the adjacent rivers and repairing storm drainage channels. Repairs involve removing silt, mud and other materials on river and drainage channels. However, social networks play an important role in assisting affected households to recover from floods.

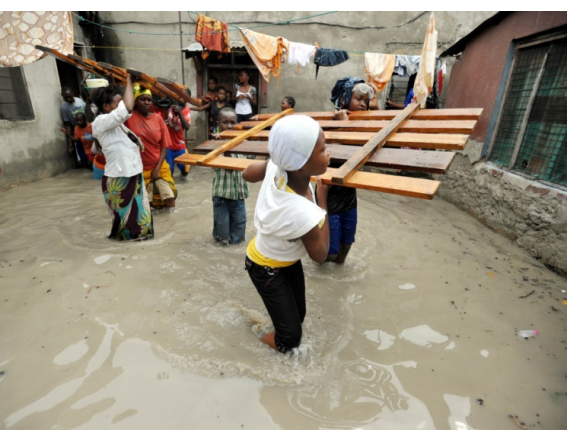

(a)

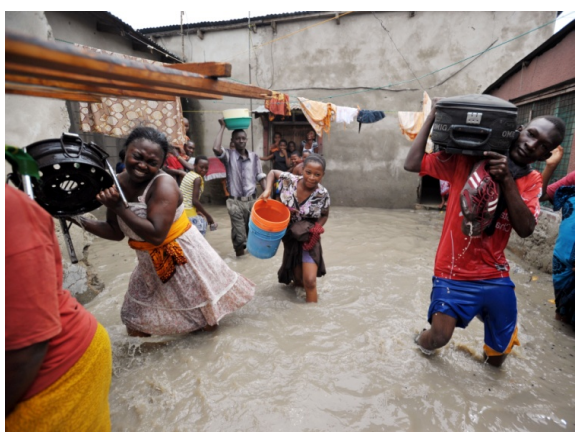

(b)

Figure 7. (a) and (b) Household trying to secure some belongings during flooding in December 2011. Source: Author, 2011. 


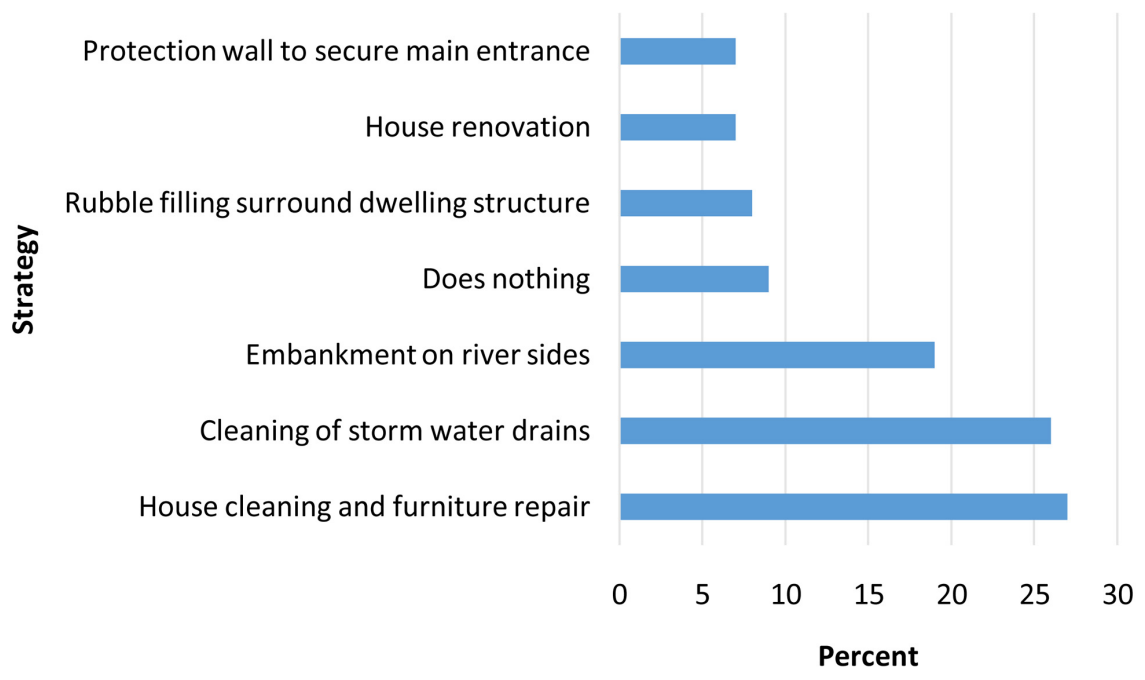

Figure 8. Responsive strategies (Multiple responses possible, $\mathrm{N}=204$ ).

\subsection{Social Networks and Institutional Support in Adaptation}

Support strategies are important for coping and adapting to flood hazards in the study area. The findings show that 77 percent of households interviewed receive support from various sources while only 23 percent receive no support (Figure 9). The type and nature of support vary considerably ranging from accommodation, material support, financial support, food, clothes, cleanness as well as securing material assets.

Respondents expressed their dependency on social networks as their focal point of relief and support. Close kin relationships formed by relatives seem to be of paramount importance in terms of providing flood recovery support to most of the affected households. Thirty-four percent of households interviewed indicated that they receive support from relatives. Another important source of support are friends, neighbors and livelihood related networks which accounts for 27 percent while political leaders with 5 percent, plays a limited role.

In addition to the important role of social networks in adaptation, institutional responses have been suggested to contribute in responding to extreme flood events. Institutions are here understood as both formal and informal organizations that either provide relief aid before, during or after hazard event and or facilitate the building of long-term resilience. These institutions can either be public, civic or private organizations.

In addressing climate change adaptation as well as disaster risk reductions, different institutions exist. They are composed of formal and informal organizations as well as governmental (local and national) and private institutions. Formal institutions include government organizations at different levels such as sub-ward, ward, municipal as well as the central government. Technically speaking, institutional structures needed to support disaster management and adaptation to climate related hazards in Tanzania and Dar es Salaam in particular are in place. However, there is widespread weakness in disaster prevention 


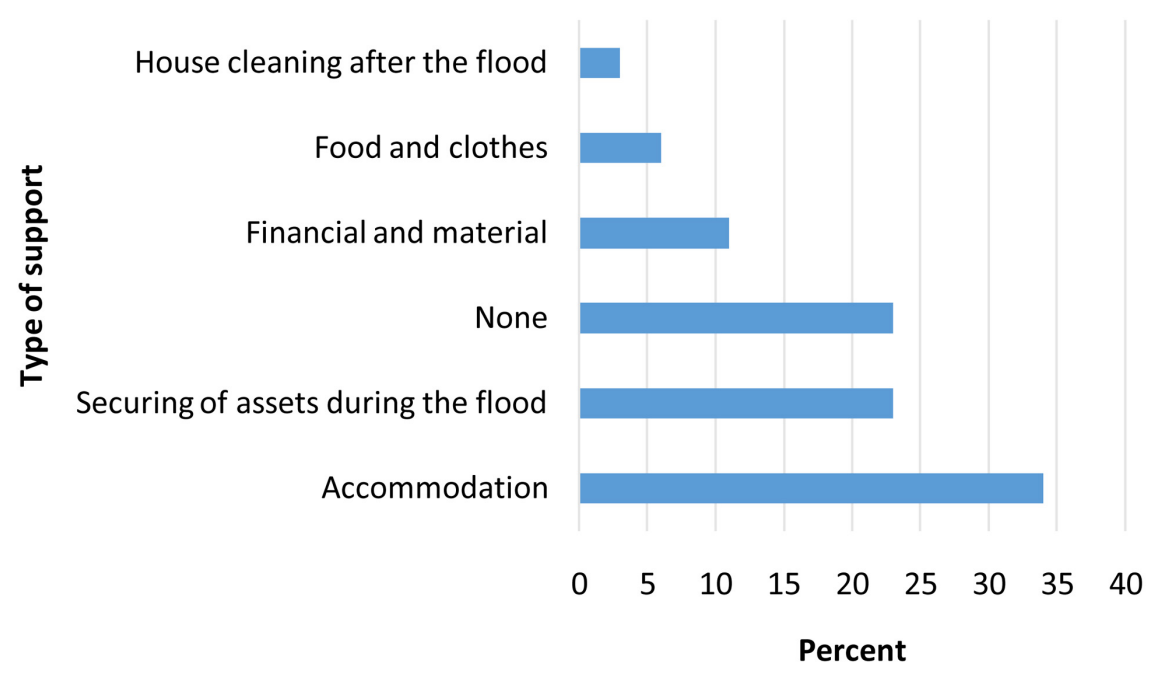

Figure 9. Type of support for coping with floods $(\mathrm{N}=199)$.

and mitigation strategies, preparedness, emergency responsive capacity and recovery options. Often there are ad-hoc arrangements in response to floods and the local government at local levels including ward and sub-ward authorities lack both financial and technical capacities to intervene. The Department of Disaster Management of the Prime Minister's Office is responsible for disaster risk management (including climate change related disasters), but with no operational capacity at the local levels of municipal, ward and sub-ward (John, 2015). During emergency situations, such as flood disaster events, the Regional and District Commissioners intervene to ensure security, safety as well as overseeing rescue processes while the Municipal and Ward governments head the emergency operations in rescuing and helping the affected residents. Lack of resource capacity to invest in adaptation measures in vulnerable communities including awareness raising on impacts of climate change and investment of basic infrastructure services especially in the informal settlement is mentioned to hinder their operations (URT, 2007; Kiunsi, 2013). At the municipal level, the Kinondoni Municipality has the formal responsibility for the provision and maintenance of road-side drainage systems in the community but often fails to regularly clean and maintain the drains.

In the absence of support from formal institutions, which are constrained by budget deficit, various other actors such as political parties, religious/faith-based organizations and NGOs (both national and international), complement household responses to flood. The Red Cross Societies for instance is a key institution that deals with rescue of households apart from providing humanitarian support such as shelter, food and medicines to households affected by floods in many parts of the city and the country at large given its capacity in terms of logistics, equipment and human resources. Figure 10 below depicts important institutions in adaptation to flood hazards in Magomeni Suna, both within and outside the settlement boundaries. 


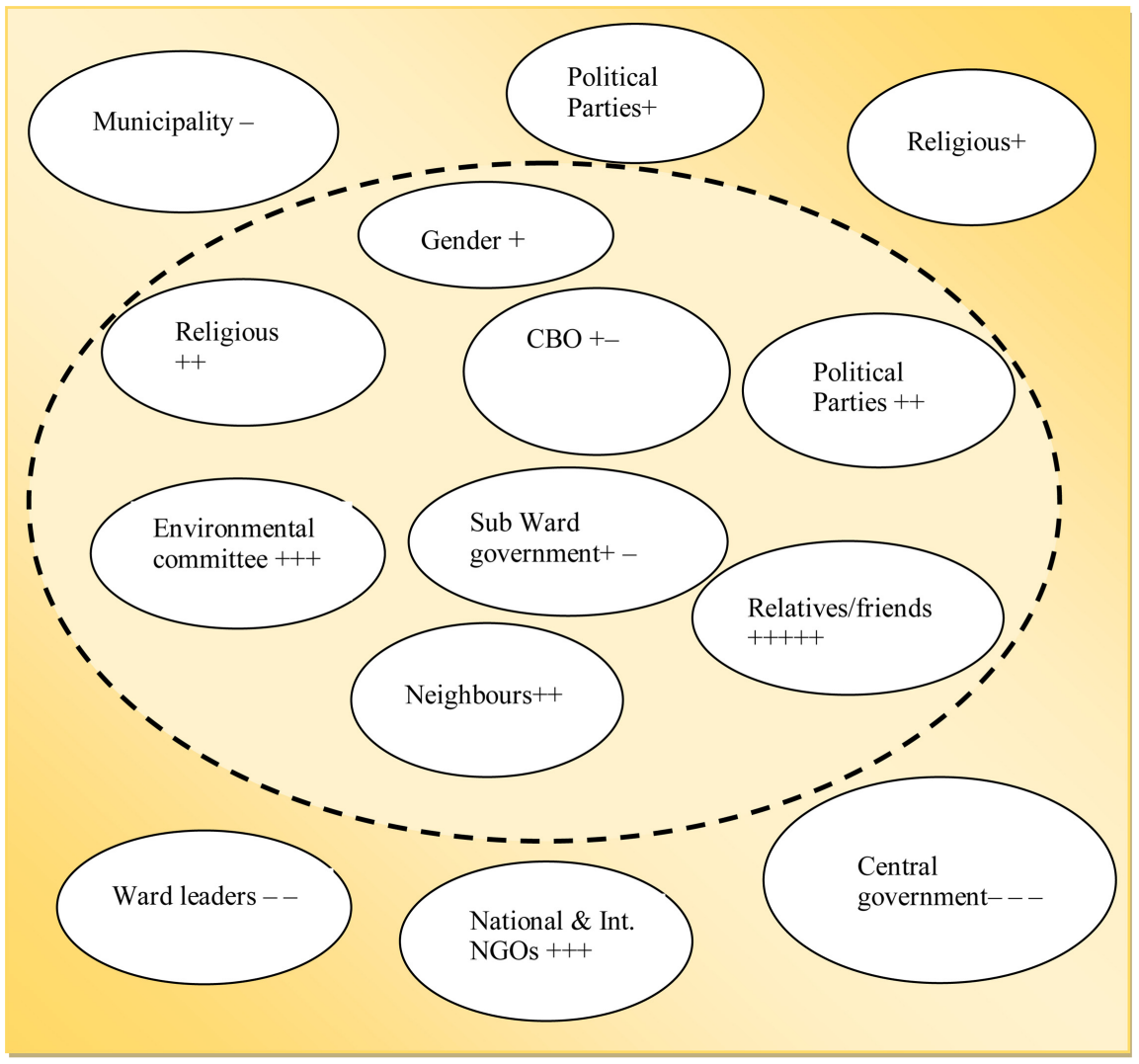

Figure 10. Important institutions for adapting to floods hazards in Magomeni Suna. Key: $++++=$ More helpful institution; --- = Less helpful; +- = More \& less helpful.

Discussions with different focus groups and interviews with key informants suggested the absence of formal government institutions to facilitate adaptation of the households against flood impacts. For instance, the residents argued that, the only formal institution that is present in the community and may or may not help during moments of stress, is the "Sub-ward government". The Sub-Ward government communicates warning information to residents (as released by the Tanzania Meteorological Agency) as well as avail rescuing places or temporary relocation centres, in most cases at the sub ward office. The Sub-Ward government however is blamed for being unable to assist the residents in taking measures before or after flooding events.

The Sub-Ward environmental committee, political parties, relatives and friends were identified to be the most important institutions for adaptation, which exists within the settlement. Other important institutions identified by the households were religious based organizations, and gender groups. However, as noted by Moser \& Ekstrom (2010), an institution may be readily present in a community but do very little to facilitate or promote adaptation of poor urban households against the impacts of adverse weather. Community Based Organizations (CBOs) were identified to be important in the community but providing little or no support for residents to adapt to flood hazards. The reason for the little support was mentioned to be lack of financial capacity as they mostly depend 
on external donor funding.

\section{Conclusion}

The key focus of this study was to explore the potentials and limits of households living in flood prone informal settlements of Magomeni Suna, along the Msimbazi River Valley, in adapting to flood hazards. The results show that households in Magomeni Suna employ multiple options for flood adaptation. The measures range from structural measures such as raising foundation and construction of embankments to prevent flood water from entering the houses, to action oriented strategies involving temporary relocation as well as moving belongings into safer, non-flood areas.

The results also indicate that households in informal flood prone settlements such as Magomeni Suna have potentials which could be harnessed to improve local adaptation measures. The potentials include strong social networks among households, which are important for support strategies. The paper has showed that existence of social networks through neighbors, relatives, friends as well as livelihood, and gender groups is vital and potential in providing immediate relief and support.

The results also showed that households in the study area are willing to volunteer and/or make financial contribution to clean river channels, thus contribute to collective flood adaptation strategies. These calls for policies aim to promote local adaptation to flood hazards to emphasize the potential of social networks and community collective actions. Enhancement of household and community collective actions can augment adaptation measures since they promote flow of resources, both financial and human, required for adaptation.

The results also highlight the role played by various local actors both formal and informal in supporting and assisting households during flood hazards. Policy interventions geared towards enhancing multi institutional involvement, both vertical and horizontal can promote the development and adoption of effective adaptation measures by households and communities.

Despite the potentials which exist, there are various limitations which impede adaptation processes of households in informal settlements. These include institutional issues like ad hoc interventions by formal government institutions mandated for climate change adaptation and disaster risk reduction, rendering the adaptation measures ineffective. The study further noted limitations related to little support from the government authorities at the local level due to lack of both financial and technical capacity. The results also noted that household in informal settlements rely on meagre income produced largely through informal business activities, which limit their ability to successfully respond to flood hazards. The vulnerable households manage flood hazards through ad hock coping mechanisms that draw on their local knowledge and capacities. These limitations call for the need to enhance capacities of local government institutions so that they can make meaningful contribution towards adaptation processes. Furthermore, policy actions towards integrating adaptation processes into development 
programs are inevitable if adaptation has to be considered an intrinsic activity of local government authorities.

Actions to promote local livelihoods are also important so as to enhance adaptive capacity of the households living in informal settlements. Majority of the low income households residing in flood prone settlements lack legal tenure on land ownership. This partly limit their adaptation processes due to lack of basic infrastructure facilities on one hand but also due to tenure insecurity supported by frequent orders by the government requiring the households to vacate from the flood prone areas. Despite a seemingly conscious decision by governments to require households live in areas free from flood risks, the findings suggest that, poor households in the flood prone informal settlements of the rapidly urbanizing cities have little options, if any to settle in safer areas given their low income levels as well as livelihood needs, which necessitate them to live in locations close to their sources of income.

Additionally, governmental efforts to steer development away from low lying areas have not been effective in the past and today they remain equally challenging given the sporadic nature of informal settlements that spring up and dominate urbanization in the city. John et al. (2014) account that some of the flood affected households who were resettled from Msimbazi valley in the year 2012 returned back to their original settlements owing to the challenges of resettlement processes. In-situ upgrading of at-risk informal settlements by investing in basic infrastructure versus relocation to safer areas, where possible could be a desired option. Low income residents may therefore benefit from locations close to jobs and services and avoid negative social impacts of relocation programs such as loss of jobs, social networks, culture and reduce urban sprawl.

The paper therefore concludes that households in the rapidly urbanizing cities of the developing countries, at least in the foreseeable future will continue to reside in informal settlements most of which are exposed to flood hazards. There is therefore a need to systematically deal with the multiple challenges for adaptation while also harnessing the existing potentials to significantly enhance adaptation of households to climate change related hazards such as floods.

\section{Acknowledgements}

The author is very grateful to Ardhi University and the Climate Change and Urban Vulnerability (CLUVA) project for covering the research costs. I also add my thanks to interviewed households, key informants, focus group discussants as well as Municipal experts for their contribution during data collection.

\section{Conflicts of Interest}

The author declares that there is no conflict of interest.

\section{References}

Adger, W. N., Agrawala, S., Mirza, M. M. Q., Conde, C., O’Brien, K., Pulhin, J., Pulwarty, 
R., Smit, B., \& Takahashi, K. (2007). Assessment of Adaptation Practices, Options, Constraints and Capacity. In M. L. Parry, O. F. Canziani, J. P. Palutikof, P. J. van der Linden, \& C. E. Hanson (Eds.), Climate Change 2007: Impacts, Adaptation and Vulnerability. Contribution of Working Group II to the Fourth Assessment Report of the Intergovernmental Panel on Climate Change (pp. 713-743.). Cambridge: Cambridge University Press.

Adger, W. N., Arnell, N. W., \& Tompkins, E. L. (2005). Successful Adaptation to Climate Change across Scales. Global Environmental Change, 15, 77-86.

https://doi.org/10.1016/j.gloenvcha.2004.12.005

Adger, W. N., Brooks, N., Bentham, G., Agnew, M., \& Eriksen, S. (2004). New Indicators of Vulnerability and Adaptive Capacity. Technical Report 7, Norwich: Tyndall Centre for Climate Change Research.

http://www.tyndall.ac.uk/theme3/final reports/it1_11.Pdf

Adger, W. N., Brooks, N., Bentham, G., Agnew, M., \& Eriksen, S. (2003). New Indicators of Vulnerability and Adaptive Capacity. Technical Report 7, Tyndall Centre for Climate Change Research, Norwich: University of East Anglia.

Adger, W. N., Dessai, S., Goulden, M., Hulme, M., Lorenzoni, I., Nelson, D. R., Naess, L. O., Wolf, J., \& Wreford, A. (2009). Are There Social Limits to Adaptation to Climate Change? Climatic Change, 93, 335-354. https://doi.org/10.1007/s10584-008-9520-z

Agrawal, A., McSweeney, C., \& Perrin, N. (2008). The Role of Local Institutions in Adaptation to Climate Change. Paper Prepared for the Social Dimensions of Climate Change. Washington DC: Social Development Department, the World Bank. https://doi.org/10.1596/28274

Biesbroek, G. R., Klostermann, J., Termeer, C., \& Kabat, P. (2013). On the Nature of Barriers to Climate Change Adaptation. Regional Environmental Change, 13, 1119-1129. https://doi.org/10.1007/s10113-013-0421-y

Blaikie, P., Cannon, T., Davis, I., \& Wisner, B. (1994). At Risk: Natural Hazards, People's Vulnerability and Disasters. New York: Routledge.

Brooks, N., Adger, W. N., \& Kelly, P. M. (2005). The Determinants of Vulnerability and Adaptive Capacity at the National Level and the Implications for Adaptation. Global Environmental Change, 15, 151-163. https://doi.org/10.1016/j.gloenvcha.2004.12.006

Cutter, S. L., Boruff, B. J., \& Shirley, W. L. (2003). Social Vulnerability to Environmental Hazards. Social Science Quarterly, 84, 242-261. https://doi.org/10.1111/1540-6237.8402002

Dodman, D., Kibona, E., \& Kiluma, L. (2011). Tomorrow Is Too Late: Responding to Social and Climate Vulnerability in Dar es Salaam, Tanzania: Case Study Prepared for Cities and Climate Change: Global Report on Human Settlements 2011.

https://www.researchgate.net/publication/228798350 Tomorrow is too late respondi ng to social and climate vulnerability in Dar es Salaam Tanzania

Eriksen, S. H., \& Kelly, P. M. (2007). Developing Credible Vulnerability Indicators for Climate Adaptation Policy Assessment. Mitigation and Adaptation Strategies for Global Change, 12, 495-524. https://doi.org/10.1007/s11027-006-3460-6

Georgeson, L., Maslin, M., Poessinouw, M., \& Howard, S. (2016). Adaptation Responses to Climate Change Differ between Global Megacities. Nature Climate Change, 6, 584-588. https://doi.org/10.1038/nclimate2944

Handmer, J. (2003). We Are All Vulnerable. The Australian Journal of Emergency and Management, 18, 55-60.

Hinkel, J. (2011). Indicators of Vulnerability and Adaptive Capacity: Towards a Clarification of the Science. Global Environmental Change, 21, 198-208. 
https://doi.org/10.1016/j.gloenvcha.2010.08.002

IPCC (2007). Climate Change 2007: Impacts, Adaptation and Vulnerability. Contribution of Working Group II to the Fourth Assessment Report of the Intergovernmental Panel on Climate Change (976 p.). Cambridge: Cambridge University Press.

IPCC (2012). Managing the Risks of Extreme Events and Disasters to Advance Climate Change Adaptation. A Special Report of Working Groups I and II of the Intergovernmental Panel on Climate Change (582 p.). Cambridge and New York: Cambridge University Press.

IPCC (2014). Climate Change 2014: Impacts, Adaptation and Vulnerability. New York: Cambridge University Press.

John, R. (2015). Social Vulnerability to Climate Change Induced Floods: A Case of Dar es Salaam City, Tanzania. Unpublished Thesis, Dar es Salaam: Department of Urban and Regional Planning, Ardhi University.

John, R., Jean-Baptiste, N., \& Kabisch, S. (2014). Vulnerability Assessment of Urban Populations in Africa: The Case of Dar es Salaam, Tanzania. In E. Edgerton, O. Romice, \& K. Thwaites (Eds.), Bridging the Boundaries: Human Experience in the Natural and Built Environment and Implication for Research, Policy and Practice (pp. 233-245). Boston, MA: Hogrefe Publishing.

Kiunsi, R. (2013). The Constraints on Climate Change Adaptation in a City with a Large Development Deficit: The Case of Dar es Salaam. Environment and Urbanization, 25, 321-337. https://doi.org/10.1177/0956247813489617

Klein, R. J. T., Midgley, G. F., Preston, B. L., Alam, M., Berkhout, F. G. H., Dow, K., \& Shaw, M. R. (2014). Adaptation Opportunities, Constraints, and Limits. In C. B. Field, V. R. Barros, D. J. Dokken, K. J. Mach, M. D. Mastrandrea, T. E. Bilir, M. Chatterjee, K. L. Ebi, Y. O. Estrada, R. C. Genova, B. Girma, E. S. Kissel, A. N. Levy, S. MacCracken, P. R. Mastrandrea, \& L. L. White (Eds.), Climate Change 2014: Impacts, Adaptation, and Vulnerability. Part A: Global and Sectoral Aspects. Contribution of Working Group II to the Fifth Assessment Report of the Intergovernmental Panel on Climate Change (pp. 899-943). Cambridge and New York: Cambridge University Press.

Moser, S. C., \& Ekstrom, J. A. (2010). A Framework to Diagnose Barriers to Climate Change Adaptation. Proceedings of the National Academy of Sciences of the United States of America, 107, 22026-22031. https://doi.org/10.1073/pnas.1007887107

Olorunfemi, F. B. (2011). Managing Flood Disasters under a Changing Climate Change: Lessons from Nigeria and South Africa. NISER Discussion Paper No. 1; a Paper Presented at NISER Research Seminar Series, NISER, Ibadan 3rd May 2011.

Parry, M. L., Canziani, O. F., Palutikof, J. P., Van der Linden, P. J., \& Hanson, C. E. (2007). Climate Change 2007 (AR4): Impacts, Adaptation and Vulnerability. Contribution of Working Group II to the Fourth Assessment Report of the Intergovernmental Panel on Climate Change (p. 976). Cambridge: Cambridge University Press.

Skoufias, E., Rabassa, M., \& Olivieri, S. (2011). The Poverty Impacts of Climate Change: $A$ Review of the Evidence. World Bank Policy Research Working Paper 5622, Washington DC: World Bank. https://doi.org/10.1596/1813-9450-5622

http://documents.worldbank.org/curated/en/712691468042044435/The-poverty-impac ts-of-climate-change-a-review-of-the-evidence

Smit, B., \& Pilifosova, O. (2003). From Adaptation to Adaptive Capacity and Vulnerability Reduction. In J. B. Smith, R. J. T. Klein, \& S. Huq (Eds.), Climate Change, Adaptive Capacity and Development (pp. 1-28). London: Imperial College Press. https://doi.org/10.1142/9781860945816 0002

Smit, B., \& Skinner, M. (2002). Adaptation Options in Agriculture to Climate Change: A 
Typology. Mitigation and Adaptation Strategies for Global Change, 7, 85-114. https://doi.org/10.1023/A:1015862228270

Smit, B., Burton, I., Klein, R., \& Wandel, J. (2000). An Anatomy of Adaptation to Climate Change and Variability. Climatic Change, 45, 223-251. https://doi.org/10.1007/978-94-017-3010-5 12

Tol, R. S. J., \& Yohe, G. W. (2007). The Weakest Link Hypothesis for Adaptive Capacity: An Empirical Test. Global Environmental Change, 17, 218-227. https://doi.org/10.1016/j.gloenvcha.2006.08.001

UN-DESA (United Nations, Department of Economic and Social Affairs, Population Division) (2019). World Urbanization Prospects: The 2018 Revision (ST/ESA/SER.A/420). New York: United Nations.

UN-HABITAT (2007). Global Report on Human Settlements, Enhancing Urban Safety and Security. United Nations Human Settlement Programme, London: Earthscan. http://www.preventionweb.net/files/2585 2432alt1.pdf

UN-HABITAT (2008). The State of African Cities 2008, a Framework for Assessing Urban Challenges in Africa. UN-HABITAT (United Nations Human Settlement Programme), Nairobi.

UN-HABITAT (2010). The State of African Cities: Governance, Inequality and Urban Land Markets. Nairobi.

UN-HABITAT (2016). World Cities Report 2016. Urbanization and Development. Emerging Futures. Key Findings and Messages. https://unhabitat.org/sites/default/files/download-manager-files/WCR-2016-WEB.pdf

URT (2007). United Republic of Tanzania, National Adaptation Programme of Action (NAPA). https://assembly.thegef.org/sites/default/files/project documents/tza01.pdf

URT (2013). 2012 Population and Housing Census: Population Distribution by Administrative Areas. Dar es Salaam: National Bureau of Statistics.

Wamsler, C. (2007). Bridging the Gaps: Stakeholder-Based Strategies for Risk Reduction and Financing for the Urban Poor. Environment and Urbanization, 19, 115-142. https://doi.org/10.1177/0956247807077029

Weichselgartner, J., \& Breviere, E. (2011). The 2002 Flood Disaster in the Elbe Region, Germany: A Lack of Context-Sensitive Knowledge. In R. A. Dowty, \& B. L. Allen (Eds.), Dynamics of Disaster: Lessons on Risk, Response, and Recovery (pp. 141-158). London: Earthscan. 